\title{
Формалізація задачі вибору перспективних рухомих засобів технічного обслуговування та ремонту військової автомобільної техніки
}

\author{
Iгор Кондратюк ${ }^{1 \text { A }}$ \\ А Національний університет оборони України імені Івана Черняховського, м. Київ, Україна
}

Received: December 5, 2021 | Revised: December 17, 2021 | Accepted: December 30, 2021

DOI: $10.33445 /$ sds.2021.11.6.11

\begin{abstract}
Анотація
Інтенсивний розвиток військової автомобільної техніки висуває підвищені вимоги до рухомих засобів технічного обслуговування та ремонту військової автомобільної техніки під час їх застосування за призначенням. Необхідно розуміти, що закупівля однієї номенклатури військової автомобільної техніки тягне за собою потребу у створенні в Збройних Сил України ремонтних комплектів для ремонтно-відновлювальних підрозділів (військових частин) різного рівня ієрархії, які будуть застосовуватись для обслуговування та ремонту даних зразків військової автомобільної техніки. Крім того необхідно враховувати, що існуючі на озброєні рухомі засоби технічного обслуговування та ремонту військової автомобільної техніки не в повній мірі пристосовані до виконання робіт на нових зразках через відсутність технологічного обладнання. Отже, на даний час виникають протиріччя між можливостями ремонтних підрозділів на озброєнні, яких знаходяться морально та фізично застарілі рухомі засоби технічного обслуговування та ремонту, і потребами у технічному обслуговуванні та ремонті нових зразків військової автомобільної техніки, прийнятих на озброєння за останні роки, в яких завершився гарантійний термін експлуатації. Застаріле обладнання існуючих рухомих засобів технічного обслуговування та ремонту, відсутність засобів діагностики, сучасних засобів зв'язку, інструменту та спеціальних приладів, які призначені для ремонту прийнятих на озброєння нових зразків військової автомобільної техніки, знижують виробничі можливості ремонтних підрозділів (військових частин), а інколи взагалі унеможливлюють повернути до строю військової автомобільної техніки, яка потребує технічного обслуговування або ремонту.

Тому, в статті на основі порівняльного аналізу можливостей рухомих засобів технічного обслуговування та ремонту і потреби в технічному обслуговуванні і ремонті нових зразків військової автомобільної техніки, характеру бойових та експлуатаційних пошкоджень військової автомобільної техніки у локальних війнах та збройних конфліктах, операції Об'єднаних сил на території України, проведене порівняння якісних та кількісних характеристик. Сформульовано наукове завдання щодо принципів побудови раціональної структури рухомих засобів технічного обслуговування та ремонту військової автомобільної техніки та їх елементів на різних рівнях ієрархії.
\end{abstract}

Ключові слова: обслуговування, ремонт, техніка, автомобіль.

\section{Постановка проблеми}

На даний час одним із основних проблемних аспектів функціонування системи відновлення озброєння та військової техніки (ОВТ) за визначених умов $€$ значне перевищення темпів розвитку та застосування засобів ураження у порівнянні із засобами захисту. Низька ефективність захисних властивостей зразків військової автомобільної

\footnotetext{
1 * Corresponding author: ад'юнкт кафедри, e-mail: igorek2410@ukr.net, ORCID: 0000-0001-9408-1435
} 
техніки (ВАТ), різнотипність базових шасі, велика номенклатура запасних частин, недосконалість системи логістичного забезпечення, а саме підсистеми технічного обслуговування і ремонту ВАТ, низькі виробничі можливості рухомих ремонтновідновлювальних органів призводить до несвоєчасного повернення зразків ВАТ В підрозділи (військові частини), які ведуть бойові дії.

3 переходом 3С України на систему логістичного забезпечення змінюються завдання, які вирішувались за допомогою рухомих засобів технічного обслуговування та ремонту (РЗТО та Р), які призначенні для підтримання В працездатномсу стані та ремонту пошкоджених зразків ВАТ [1-3]. В свою чергу, це вимагає модернізації і розробки нових, перспективних РЗТО та Р, які б в свою чергу відповідали вимогам сьогодення щодо технічного обслуговування і ремонту (ТО і Р) ВАТ в польових умовах та під час ведення бойових дій [4]. На даний час для вирішення цих завдань використовуються існуючі на озброєнні ЗС України РЗТО та Р ВАТ, які залишились з часів Радянського Союзу та які за функціональними можливостями виконують обмежене коло конкретних завдань. Закупівля нових зразків ВАТ призводить до збільшення номенклатури базових шасі відповідно існуючі РЗТО та $\mathrm{P}$ невзмозі охопити увесь спектр завдань. Враховуючи те, що РЗТО та Р ВАТ які призначені для проведення ТО і Р на зразках ВАТ $\epsilon$ невід' $є$ Мною частиною системи ТО і Р 3 С України, процес формування їх типажу повинен грунтуватися на системному підході.

Разом з цим, відповідно до основних напрямів розвитку ОВТ на довгостроковий період, одним з основних завдань політики держави у сфері оборони є підтримання в боєздатному стані Збройних Сил України, інших утворених відповідно до законів військових формувань сектору безпеки і оборони та оснащення їх новітніми зразками озброєння та військової (спеціальної) техніки для забезпечення захисту державного суверенітету і територіальної цілісності держави. На цей час, однією із загроз щодо суверенітету i територіальної цілісності України є триваюча агресія Російської Федерації, що потребує упровадження необхідних способів протидії, удосконалення підходів до формування військово-технічної політики держави 3 урахуванням нагальної необхідності оновлення наявного озброєння та військової (спеціальної) техніки [5-6]. Також стоїть необхідність розроблення високоефективних, багатофункціональних нових та модернізація технічних засобів ТО і Р ОВТ, в тому числі модульного типу, 3 підвищеними характеристиками мобільності, автономності, продуктивності, економічності та необхідним рівнем захищеності особового складу. Тому, оснащення ЗС України високопродуктивними РЗТО та Р ВАТ зумовлено виконанням завдань в складній оперативно-тактичній обстановці. Для розроблення i впровадження у виробництво нових перспективних зразків (комплексів, систем) озброєння та військової (спеціальної) техніки необхідно створити перспективну систему забезпечення ЗС України, як основну складову сектору безпеки $\mathrm{i}$ оборони держави [5-6].

Отже, закупівля нових та модернізація існуючих зразків ВАТ спонукає до пошуку та створення нових, ефективних і перспективних РЗТО та Р, які $б$ відповідали сучасним умовам щодо ТО і Р ВАТ в польових умовах та під час ведення бойових дій. Це дозволить вчасно, якісно та ефективно підтримувати зразки ВАТ в бойовій готовності до застосування.

Аналіз ведення бойових дій на тереторії Донецької та Луганської областей України виявив низку невідповідностей під час застосування РЗТО та Р ВАТ. Визначені невідповідності обумовлюють необхідність у створені нових перспективних РЗТО та Р ВАТ, що дозволить об'єднати розрізнені евакуаційні й ремонтні підрозділи в єдиний орган (механізм), який забезпечить виконання поставлених завдань з ТО і Р ВАТ в польових умовах або під час ведення бойових дій на різних рівнях ієрархії у відповідності до обсягів визначених завдань. 


\section{Аналіз останніх досліджень та публікацій}

Аналіз публікацій показав, що дослідженню питань щодо розвитку РЗТО та Р присвячена ціла низка робіт, зокрема у роботі [7] розглядаються основні задачі, які розв'язуються при організації та управлінні складними організаційно-технічними системами, а також необхідність використання структурного синтезу під час формалізації задач основних параметрів системи відновлення. Робота [8] присвячена аналізу військових технічних систем 3 метою виявлення проблемних питань та пошуку шляхів для їх вирішення. Запропоновано підхід щодо підвищення ефективності функціонування системи автотехнічного забезпечення. В роботі [9] запропоновано концептуальні основи розробки програм забезпечення ремонтопридатності складних технічних систем. Розглянуто проблеми забезпечення ремонтопридатності для сучасних складних технічних систем. У роботі [10] визначено, що розглянуті методичні основи являються основою для обґрунтування вимог до ремонтопридатності складних технічних систем військового призначення. В роботі [11] досліджується можливість реалізації нових інформаційних технологій на етапі експлуатації озброєння, для оцінювання загального стану та якості функціонування системи інтелектуальної підтримки процесу експлуатації. Окремі аспекти даної проблематики викладені у роботі [12], у якій запропоновано математичну модель багатокритеріального вибору автомобільної техніки. У роботі [13] запропоновані підхід до вирішення проблем невизначеності при обґрунтуванні завдань, який базується на комплексному аналізі процесів функціонування. Деякі питання даної проблематики розглянуто у роботі [14], у якій запропоновано підхід до обґрунтування заходів з підтримання бойової готовності та боєздатності парків ОВТ. В літературних джерелах [15-16] проведено аналіз розвитку ОВТ та засобів їх ремонту у провідних країн світу і в Україні та розглянуто проблеми, які вливають на розвиток ОВТ. У роботі [17] проведений аналіз та порівняння сучасного парку рухомих засобів технічного обслуговування та ремонту ВАТ, які знаходяться на озброєнні Збройних Сил України, країнах ближнього і дальнього зарубіжжя. Де, виходячи із аналізу виникає необхідність у розробленні нових підходів які покращать тактико-технічних характеристик рухомих засобів відновлення ВАТ для застосування у різних формах та способах бойових дій. Також, деякі питання розглянуті у роботі [18], де враховуючи потребу в проведенні технічного обслуговування i ремонту військової автомобільної техніки визначено невідповідності у можливостях існуючих на озброєнні рухомих засобів відновлення ВАТ. Визначено, що в основі формування РЗТО та Р з урахуванням завдань, які покладаються на ремонтновідновлювальні підрозділи повинні лежати три основних принципи: базовий, мобільний, блочно-модульний. В роботі [19] розглядаються питання методичного апарату щодо визначення виробничих можливостей ремонтно-відновлювальних органів. В роботі [20] запропоновано підхід до формалізації задачі розподілу технопарків між регіонами та вказані можливі підходи до вирішення цієї задачі. У роботі [21] запропоновано метод моделювання на основі комплексного підходу, який базується на побудові i дослідженні математичної моделі системи забезпечення боєздатності парку ОВТ угруповання військ. Також, у роботі [22] запропоновано підхід до оцінювання ефективності застосування РЗТо та Р. Робота [23] стосується аналізу шляхів розвитку рухомих засобів ремонту озброєння та військової техніки. Проаналізовані рухомі засоби ремонту, розроблені військовопромисловим комплексом Білорусії та Російської Федерації в основі яких покладено застосування системи "мультиліфт", а робота 
[24] присвячена методичним підходам щодо формування тактико-технічних вимог до технічних засобів відновлення ОВТ. Дозволяє обґрунтувати тенденції розвитку та принципи будови рухомих засобів технічного обслуговування і ремонту ОВТ. Але не враховано, що на різних рівнях ієрархії обсяг завдань з ремонту ОВТ буде відрізнятись, тим самим використання однотипних рухомих засобів ремонту ОВТ $\epsilon$ економічно недоцільним. В роботі [25] проведений аналізу спроможностей вітчизняних підприємств щодо розробки та виробництва сучасних рухомих ремонтних майстерень військової автомобільної техніки. Найбільш доцільний варіант побудови автомобільних платформ відображено у публікаціях [26-27] суть яких полягає у розробленні однотипних гусеничних та колісних платформ побудованих за модульним принципом. Також передбачається їх розподілити на три класи важкі, середні та легкі та в подальшому

\section{Постановка завдання}

Тому, мета статті полягає у формулюванні наукового завдання та обґрунтуванні сукупності принципів побудови в залежності від потреби військ встановлювати на дані платформи відповідні модулі озброєння, вантажні модулі, модулі засобів ремонту.

Отже, майже в усіх доступних джерелах, розглядаються питання ефективності застосування РЗТО та Р ВАТ, способи технічного обслуговування і ремонту зразків ВАТ та пропонуються напрямки їх удосконалення. Проте, В плані розробки загальних підходів на основі системного підходу вирішено лише часткові задачі, що не дозволяє у повному обсязі обґрунтувати тактико-технічних вимоги до параметрів перспективних РЗТО та Р ВАТ.

Недосконалість існуючого методичного апарату обумовлює потребу у вирішенні наукового завдання сутність якого полягає в обґрунтуванні сукупності принципів побудови перспективних РЗТО та Р ВАТ в польових умовах або під час ведення бойових дій.

перспективних рухомих засобів технічного обслуговування та ремонту військової автомобільної техніки.

\section{Виклад основного матеріалу}

Кількість РЗТО та Р ВАТ у військових частинах та підрозділах ЗС України обумовлена обсягами виконання робіт щодо обслуговування і ремонту ВАТ в польових умовах та під час ведення бойових дій в задані терміни.

Разом 3 цим, існуючі РЗТО та $\mathrm{P}$ які знаходяться на озброєнні у ЗС України, $\epsilon$ застарілою спадщиною колишнього Радянського Союзу. Вимоги до них визначалися задачами, які відповідали воєнно-політичним поглядам тодішнього керівництва щодо ведення збройної боротьби та рівню розвитку ВАТ, виробничим можливостям оборонно-промислового комплексу тих часів [28].

Переважна більшість РЗТО та Р ВАТ, які знаходяться на озброєнні ремонтновідновлювальних органів розроблена в другій половині минулого століття [29]. Дані засоби характеризуються моральним та фізичним старінням, деякі засоби функціонально дублюють інші, відсутністю можливості проводити ТО і ремонтні роботи на зразках ВАТ, які за останні вісім років були прийняті на озброєння або допущені до експлуатації В ЗС України. Засоби, які призначені для ТО і Р ВАТ за своїми тактикотехнічними характеристиками не в змозі в повному обсязі виконувати завдання з ТО і Р на зразках ВАТ. При цьому значна частина 3 них виготовлялася за межами України, а деякі зняті з виробництва понад 20 років тому [30].

Досвід застосування РЗТО та Р ВАТ У воєнних конфліктах XXI ст., миротворчих операціях, операції Об'єднаних сил (ООC) (антитерористичній операції (АТО)) показав, невідповідність тактико-технічних 
характеристик окремих типів РЗТО та Р 3 усунення пошкоджень які отримували ВАТ.

Необхідність створення нових зразків ВАТ, 3 одного боку, та обмежені економічні можливості держави, з іншого, змушують здійснювати пошук найбільш доцільної шляхів створення перспективних РЗТО та Р враховуючи матеріальні та економічні передумови. У сучасних умовах економічного розвитку держави та несиметричної переваги загальносвітових темпів розвитку засобів ураження й застосування інших видів зброї, спроби досягти паритету в розвитку РЗТО та Р неминуче ведуть до відставання.

В загальній якісній характеристиці РЗТО і Р ВАТ слід розглядати техніко-економічну ефективність. Альтернативою в даному випадку є принцип асиметричного розвитку різних типів засобів ТО і Р, який в рамках розвитку ЗС України полягає у виборі різного типажу даних засобів та введенні їх у раціональному співвідношенні до системи логістичного забезпечення [31]. На цей час немає цілісного структурно-параметричного синтезу РЗТО та Р для виконання специфічних завдань з ТО і Р ВАТ на різних рівнях ієрархії, елементи якої відповідали б новим зразкам ВАТ, що й обумовлює одне із ключових наукових завдань. Внаслідок чого, в практиці створення перспективних РЗТО та Р виникає проблема розробки та виробництва високоефективних і економічно доцільних засобів ТО іР ВАТ, застосування яких дозволило $б$ підвищити якість проведення ТО і Р ВАТ та знизити їх вартість.

Отже, наукове завдання спрямоване на вирішення протиріччя між сучасними вимогами до рівня функціональної ефективності РЗТО та Р ВАТ та їх елементів і рівнем розвитку теоретичних основ їх побудови. Розв'язання цього завдання ґрунтується на системному підході та передбачає комплексний розгляд широкого кола питань $з$ ефективності застосування РЗТО та Р ВАТ під час виконання завдань за призначення. Вирішуючи завдання в усіх напрямках одночасно, необхідно враховувати як економічні можливості, так і пріоритети в завданнях, які виконуються із застосуванням РЗТО та Р ВАТ на основі яких розробити підхід до формування перспективних РЗТО та Р ВАТ.

Аналіз підходів та методів функціонування РЗТО та Р розподілених у просторі та часі, дає змогу зробити висновок про наявність невідповідності між їх можливостями та вимогами, які сьогодні висуваються до них. Суть такої невідповідності полягає у наступному:

виникає складність в проведенні ТО і Р під час експлуатації нових зразків ВАТ, непристосованість РЗТО і $\mathrm{P}$ до виконання завдань в польових умовах, низька потужність евакуаційних та підйомних засобів, відсутність запасних частин і відповідних експлуатаційних матеріалів, технічної документації для проведення ТО і P; відсутність навчених спеціалістів 3 обслуговування та ремонту, тощо;

існуючі на озброєнні ЗС України РЗТО та $\mathrm{P}$ ВАТ не адаптовані до проведення на нових зразках ВАТ технічного обслуговування та ремонту в польових умовах або під час ведення бойових дій;

на всіх рівнях ієрархії знаходяться рухомі засоби ТО та Р ВАТ, які технологічно призначені для виконання однакового обсягу завдань, при цьому обсяг завдань на усіх рівнях ієрархії різний. Дані обставини призводять до того, що на тактичному рівні використовується не усе технологічне обладнання, а на оперативному та стратегічному його не вистачає;

виникає потреба зменшення витрати часу на виконання технологічних операцій в той час як існуючі РЗТО та Р характеризуються застарілим обладнанням, яке своїми характеристиками морально та фізично застаріло, через не спроможність виконувати завдання з необхідною продуктивністю;

зменшення номенклатури засобів технічного обслуговування і ремонту ВАТ, у той час, як вимога щодо зменшення витрат на функціонування вимагає застосування 
засобів ТО і Р на єдиній базовій уніфікованій платформі;

використання високопродуктивних РЗТО та Р модульного типу в польових умовах або під час ведення бойових дій в той час неможливість забезпечення їх через велику кількісну потребу та вартість;

потреба у врахуванні різної складності обсягів робіт, які необхідно виконувати з ТО і Р зразків ВАТ наявним обладнанням, у той же час виникає нераціональне використання обладнання для виконання завдань різної складності;

потреба у побудові перспективних РЗТО та Р ВАТ для різних рівнів ієрархії у той час як обсяг ремонту ВАТ на різних рівнях ієрархії за обсягом трудомісткості робіт різний;

виникає потреба в укомплектованості відповідними ремонтними комплектами і експлуатаційними матеріалами РЗТО та Р для проведення ТО і Р на нових зразках ВАТ.

Зазначені протиріччя обумовлюють необхідність наукового обґрунтування тактико-технічних вимог до перспективних РЗТО та Р щодо ТО і Р сучасної ВАТ на різних рівнях ієрархії.

Створення таких засобів необхідно орієнтувати на автономне виконання комплексу робіт з технічного обслуговуванню і ремонту ВАТ від рівня батальйону.

Обладнання таких засобів повинно забезпечувати виконання в повному об'ємі комплексу робіт з ТО і Р ВАТ, а також виконання найбільш складних операцій в польових умовах та під час ведення бойових дій.

Така потреба у створенні перспективних РЗТО та Р ВАТ $\epsilon$ комплексною і поєднує розробки у багатьох галузях науки, а саме теорії надійності ВАТ, теорії проектування РЗТО і Р , теорії складних технічних систем тощо.

Проведений аналіз щодо проблем ТО і P нових зразків ВАТ показав, що протиріччя між можливостями існуючих РЗТО та Р ВАТ $\mathrm{i}$ вимогами до них так і не вирішені.

Разом з цим, тактико-технічні вимоги, які висуваються до РЗТО і Р ВАТ, обумовлюються тим, що на різних рівнях ієрархії обсяг робіт 3 ТО і Р різний, а також номенклатура ВАТ, яка знаходиться в підрозділах (військовій частині) різні.

Тому, актуальність питання, яке розглядається, обумовлюється невідповідністю науково-методичного апарату обґрунтування процесів ТО і P нових зразків ВАТ та обумовлює необхідність вирішення наукового завдання щодо розвитку теорії структурно-параметричного синтезу та принципів побудови перспективних рухомих засобів ТО і Р ВАТ.

Для формалізації поставленого наукового завдання на основі теоретико-множинного підходу представлено модель перспективних РЗТО і Р ВАТ, як

$$
R Z T R_{\mathrm{BAT}}=\langle A, D, F, Z, \operatorname{Pr}, S p, C k, N, Q(Z), C(Z), t((Z)\rangle
$$

де $R Z T R_{\mathrm{BAT}}-$ РЗТО та Р ВАТ;

$A-$ множина елементів РЗТО та Р ВАТ;

$D$ - множина зв'язків між елементами РЗТО та Р ВАТ;

$F$ - функції, які призначені елементам РЗТО та Р ВАТ;

$Z$ - множина завдань РЗТО та Р ВАТ;

$\mathrm{Pr}$ - множина процесів у РЗТО та Р ВАТ;

$S p$ - середовище застосування РЗТО та Р BAT;

$C k$ - складність процесів ТО і Р ВАТ;
$N$ - імовірний вихід РЗТО та Р з ладу від експлуатаційних або бойових пошкоджень;

$Q(Z)$ - показники якості виконання завдання;

$C(Z)$ - показники вартості РЗТО та Р ВАТ;

$t(Z)$ - час, який витрачається на виконання завдань з ТО і Р ВАТ.

Робота рухомих засобів технічного обслуговування та ремонту (1) може бути подана у вигляді

$$
A \times D \times F \times \operatorname{Pr} \times S p \times C k \rightarrow Z^{* *}
$$


Однією з основних вимог, які висуваються до РЗТО та Р ВАТ $€$ вимога щодо їх працездатності (функціонування). Тобто обсяги виконаних завдань $Z$, які залежать від множини характеристик РЗТО та Р ВАТ Pr, повинні бути максимальними при дотриманні вимог щодо збереження

$$
Z \in Z^{*}, Q(Z) \geq Q^{*}(Z), C(Z) \leq C^{*}(Z), t
$$

де $Q^{*}(Z), C^{*}(Z), t^{*}, C k_{j}^{*}$ - деякі граничні показники, встановлені оперативнотактичними вимогами;

$\langle k, h, g\rangle$ - параметри складності процесів TO i P BAT;

$k$ - кількість зразків ВАТ, які отримали експлуатаційні (бойові) пошкодження, од;

$h$ - трудомісткість робіт з ТО і Р ВАТ, люд/год;

$g$ - номенклатура зразків ВАТ, які вийшли 3 ладу).

Отже, деталізуючи сформульоване наукове завдання, потрібно визначити таку побудову РЗТО та Р ВАТ при якій цільова функція їх застосування набуває максимального значення серед всіх можливих варіантів їх побудови

$$
\alpha=\langle v, d, f\rangle: \arg \max \left[W\left(N_{V A T_{i}} C k_{i}\right)\right]
$$

3 метою підвищення ефективності ТО і Р ВАT на тактичному, оперативному та стратегічному рівнях пропонується застосування їх елементів у відповідності до обсягів завдань різної складності із урахуванням пристосування до нових зразків ВАТ для проведення робіт з ТО і Р. Побудову зазначених РЗТО та Р ВАТ пропонується здійснити на основі адаптації їх до нових зразків ВАТ на різних рівнях ієрархії, а також за рахунок реалізації обґрунтованих раціональних параметрів та структури РЗТО та Р ВАТ, функціонування яких може бути представлено у вигляді канонічної моделі. Дана модель являє собою групу вихідних даних, отриманих на основі прогнозування обстановки і потоку ремонтного фонду, без яких неможливо обґрунтувати тактикотехнічні вимоги до РЗТО та Р ВАТ (рис. 1). необхідної кількості та якості їх виконання $Q(Z)$, в умовах часових обмежень.

Тобто, у формалізованому вигляді завдання може бути представлено, як

$$
W\left(N_{V A T} ; C_{k}\right) \rightarrow \max ;
$$

при

$$
t(Z) \leq t^{*}, C k_{i j} \geq C k_{j}^{*}, C k_{i}=\langle k, h, g\rangle
$$

Відповідно до зображеної на рис. 1 схеми, для вирішення завдання 3 технічного обслуговування і ремонту ВАТ повинна використовуватись мінімально необхідна кількість РЗТО та $\mathrm{P}$ із різним часовопросторовим розмахом. Це дасть змогу значно зменшити необхідну, для досягнення встановленого рівня ефективності, кількість РЗТО та P і обґрунтувати необхідний типаж РЗТО та Р ВАТ для різних рівнів ієрархії.

Вищезазначені чинники безпосередньо пов'язані з особливостями застосування РЗТО та Р і не потребують окремого обґрунтування. Разом з тим, функціонування РЗТО та Р ВАТ повинно відповідати загальним завданням 3 ТО і Р, які вирішуються в польових умовах або під час ведення бойових дій, а їх структура має забезпечувати отримання найбільшого ефекту від виконання робіт з ТО і Р ВАТ. Отже, виникає необхідність в обґрунтуванні сукупності основних принципів побудови РЗТО та Р ВАТ, при цьому, для попереднього оцінювання їх ефективності можливо скористатись результатами, наведеними в роботах [32-39]. Слід зауважити, що в цілому зазначені принципи ґрунтуються на загальних принципах ТО і Р ОВТ [40].

Для адекватного формулювання принципів розглянемо простір $X$ зовнішніх показників, які впливають на функціонування РЗТО таі Р. Відповідно до роботи [41] можна виділити наступні групи таких показників: фізико-географічні показники $x_{\phi 2}$; показники, що характеризують характер дій противника $x_{\text {пр }}$, та його можливості щодо ураження ВАТ; показники, які характеризують характер дій своїх військ, а також можливості щодо ТО і P BAT $x_{c B}$. 


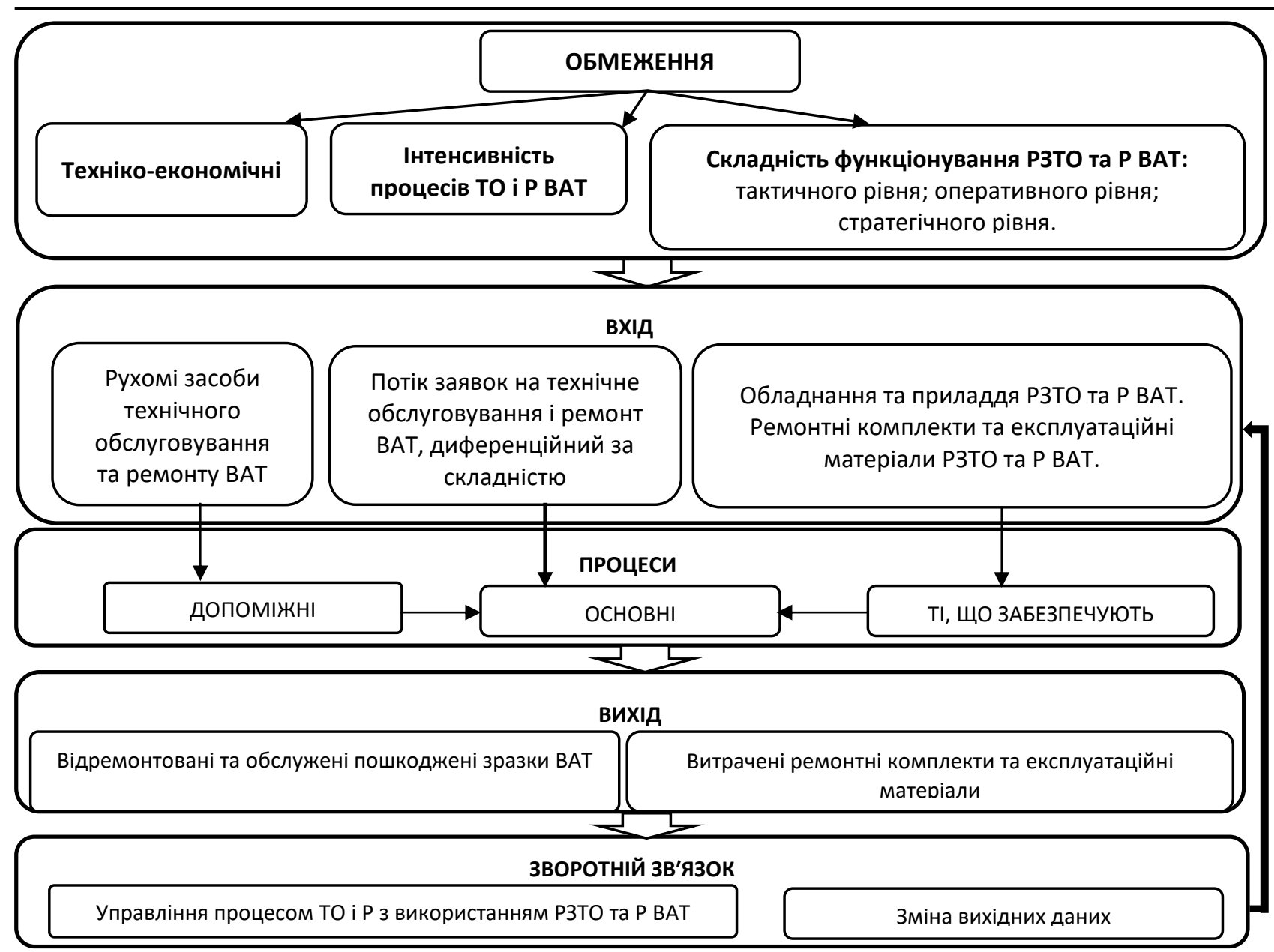

Рисунок 1 - Функціональна схема процесів які виконують РЗТО та Р з ТО і Р ВАТ

В свою чергу, враховуючи динамічний характер сучасних бойових дій, можна відзначити, що на інтервалі часу $T$, протягом якого розглядається функціонування РЗТО і Р ВАТ, вказані показники можуть мати вигляд кортежу: $\quad x=\left\langle x_{\phi \Gamma}, x_{\text {пр }}, x_{\mathrm{cB}}, t\right\rangle, \quad$ який характеризує поточний стан зовнішніх показників, які впливають на функціональну ефективність РЗТО та Р ВАТ в цілому.

Тоді узагальнений показник функціональної ефективності $W$ РЗТО та Р ВАТ можна представити у вигляді $W=W(\alpha, x)$, а вибір кращого варіанту структури зазначених РЗТО та Р ВАТ - проводити за критерієм максимізації узагальненого показника.

Запропонований формалізований опис завдання дає змогу сформулювати основні принципи [42] побудови РЗТО та Р.
Перш за все слід визначити принцип відповідності структури РЗТО та Р ВАТ рівням iєрархії:

$$
\forall \alpha, x_{k}: W\left(\alpha_{i}, x_{j}\right) \rightarrow \max ,
$$

де $\alpha_{i}$ - один з варіантів структури РЗТО та Р BAT;

$x_{k}, x_{j}$ - варіанти на рівнях ієрархії РЗТО та Р BAT $k, j \in 1,|x|$.

В якості наступного принципу побудови РЗТО та Р ВАТ розглянемо принцип модульності. Зазначений принцип передбачає наявність структурних елементів, можливість їх взаємозаміни, а також збільшення загальної ефективності рухомих засобів ТО і Р ВАТ в разі збільшення ефективності їх окремих модулів. Виконання першої 3 наведених умов витікає 3 формалізації рухомого зразка (наявність 
множини $A$ ). Розглянемо певні підмножини узагальненого показника функціональної (модулі) $\quad p, q \subseteq V$ та відображення $\quad W-$ ефективності РЗТО та Р ВАТ, тоді:

$$
\left.\begin{array}{l}
v_{1}=\langle p\rangle \\
v_{2}=\langle p, q\rangle
\end{array}\right\} \Rightarrow \begin{aligned}
& v_{1}<v_{2} \rightarrow C\left(\alpha_{1}\right)<C\left(\alpha_{2}\right) \\
& W\left(\alpha_{2}\left\langle v_{1}, d, f\right\rangle, x\right) \geq W\left(\alpha_{1}\left\langle v_{1}, d, f\right\rangle, x\right)
\end{aligned}
$$

де $v_{1}$ - рухомий зразок ТО і Р ВАТ, для виконання завдань на нижчому рівні ієрархії; $v_{2}$ - рухомий зразок ТО і Р ВАТ, для виконання завдань на вищому рівні ієрархії.

Як уже відзначалося, під час ведення бойових дій можуть виникати різні варіанти значень показників зовнішніх факторів, що можуть характеризувати різні ситуації щодо ТО і Р ВАТ. Відповідно до цього, низька ефективність РЗТО та Р ВАТ та неякісне виконання робіт з ТО і Р ВАТ на різних рівнях ієрархії не дозволить забезпечити високий рівень ефективності застосування військових частин, підрозділів в цілому. Створення перспективного типу РЗТО і Р ВАТ на різних рівнях ієрархії дозволить забезпечити необхідну гнучкість до тих чи інших ситуацій в проведенні ТО і Р ВАТ. Разом з цим, $\epsilon$ можливим створення та утримання частини структури РЗТО та Р ВАТ $\alpha^{\min }$ на основі введеного принципу мінімальної достатності. Даний принцип потребує забезпечення мінімально достатнього рівня ефективності функціонування рухомих засобів ТО і Р ВАТ $W^{\text {min } д л я ~ б у д ь-я к и х ~ м о ж л и в и х ~ з н а ч е н ь ~}$ показників зовнішніх факторів:

$$
\forall a_{i} \rightarrow \alpha^{\min } \text { при } W\left(a_{i}, x_{k}\right) \geq W^{\text {min }}
$$

За наявності достатньо ефективних РЗТО та Р ВАТ противником будуть вживатися відповідні заходи щодо протидії, у зв'язку з чим, певні елементи рухомих засобів ТО і $\mathrm{P}$ будуть вражатися та виводитися 3 ладу. Також можливий вихід з ладу елементів РЗТО та Р ВАТ з експлуатаційних причин. Крім того, необхідно забезпечити можливість надійності структури елементів РЗТО та Р відповідно до зовнішніх умов, що склалися на певний період часу $t$.

На наступному етапі визначимо принцип надійності певної частини елементів РЗТО та Р ВАТ для їх подальшого функціонування:

$$
t<t\langle v, d, f\rangle^{\prime}\left\langle v^{\prime}, d^{\prime}, f^{\prime}\right\rangle_{\max }, \text { при } v^{\prime}>v ; d^{\prime}>d ; f^{\prime}>f,
$$

де $t_{\text {max }}-$ кінцевий час застосування РЗТО та Р BAT.

Тоді, спираючись на опис попередніх двох принципів (5), (6) для моментів часу $t_{1}, t_{2}$ функціонування РЗТО та Р ВАТ сформулюємо принцип відновлення:

$$
W\left(a_{i}, x_{k}\right) \geq W^{\min _{t_{1}} t_{2}} ; t_{1}<t_{2}
$$

Відповідно до виразу (7) через деякий час відбувається використання відновлюваних елементів РЗТО та Р ВАТ. При цьому, з одного боку, підтримується частина структури РЗТО та $\mathrm{P}$, яка відповідає принципу мінімальної достатності (5), а з іншого - загальна структура надійності елементів РЗТО та Р (6).

Під час побудови принципів застосування РЗТО та $\mathrm{P}$ ВАТ визначаласяь наявність дестабілізуючих впливів на рухомі засоби, які призводять до виходу з ладу певних їх елементів та відповідного зниження їх функціональної ефективності. Відповідно до цього, під час структурно-параметричного синтезу таких РЗТО та Р ВАТ, розглядається властивість функціональної стійкості - як властивості РЗТО та Р, що полягає в здатності виконувати хоча б встановлений мінімальний об'єм своїх завдань в умовах впливу 
зовнішніх факторів, які передбачені умовами експлуатації РЗТО та Р ВАТ.

Вищезазначене дає змогу висунути принцип функціональної стійкості РЗТО та Р ВАТ загальна ідея якого полягає у створенні необхідного запасу $(\Delta v, \Delta d, \Delta f)$ та забезпечення можливості застосування їх в позаштатних ситуаціях під час виконання завдань за призначенням, які виникають в процесі їх застосування. Принцип функціональної стійкості РЗТО та Р ВАТ можливо сформулювати як

$$
\left.\begin{array}{l}
\forall v \subseteq V \exists v^{+}, v \\
\forall d \subseteq D \exists d^{+}, d \\
\forall f \subseteq F \exists f^{+}, f \\
\langle\Delta v, \Delta d, \Delta f\rangle \neq
\end{array}\right\} \Rightarrow \alpha\langle\Delta v, \Delta d, \Delta f\rangle \rightarrow W\left(a_{i}, x_{k}\right) \geq W^{\min }
$$

\section{Висновки}

Отже, у даній статті наведена формалізація наукового завдання на основі теоретикомножинного підходу і $є$ новим підходом у галузі побудови складних технічних систем, зокрема, до побудови РЗТО та Р ВАТ та запропонована сукупність основних принципів. Також сформульовані на основі канонічної моделі принцип відповідності побудови РЗТО та Р ВАТ на різних рівнях ієрархії, принципи модульності, мінімальної достатності, надійності певної частини елементів РЗТО та Р ВАТ, відновлення, функціональної стійкості РЗТО та Р ВАТ. Дані принципи визначають ефективність застосування перспективних РЗТО та Р ВАТ і мають на меті їх постійне удосконалення.

В подальшому $\epsilon$ необхідність проведення досліджень, щодо обґрунтування тактикотехнічних вимог до РЗТО та Р, які діятимуть на різних рівнях ієрархії.

\section{Список використаних джерел}

1. Гаврилюк І.Ю., Мацько О.Й., Дачковський В.О. Концептуальні основи управління потоками В системі логістичного забезпечення Збройних Сил України. Сучасні інфоомаційні технології у сфрері безпеки та оборони, НУОУ. 2019. № 1(34) С. $37-44$.

2. Власов, І. О. Воробйов, О. М. Наконечний, О.В.Середа, Ю.С.Обґрунтування концептуальних та наукових підходів щодо розвитку єдиної системи логістики в Збройних Силах України. Збірник наукових праць Харківського національного університету Повітряних Сил імені Івана Кожедуба. 2020. № 2(64). С. 12-18.

3. Kyvliuk, V., \& Gannenko, Y. (2018). Improvement of the system of material resources of the armed forces of Ukraine. Journal of Scientific Papers "Social Development and Security», 4(2), 49-58. DOI: 10.5281/zenodo.1231404
4. Dachkovskyi, V. (2019). Methodology of justification of tactical and technical requirements for movable means of repairing arms and military equipment. Journal of Scientific Papers "Social Development and Security», 9(6), 86-101. DOI: 10.33445/sds.2019.9.6.7

5. Розпорядження Кабінету Міністрів України від 14 червня 2017 р. № 398-р, м. Київ. URL: https://zakon.rada.gov.ua/laws/show/3982017-p\#Text.

6. Розпорядження Кабінету Міністрів України від 21 липня 2021 р. № 825-p м. Київ. URL: https://zakon.rada.gov.ua/laws/show/8252021-\%D1\%80\#Text.

7. Шишанов, М. О. Шевцов, М. М. Чеченкова, О. Л. Методологічні основи структурного синтезу систем відновлення озброєння та військової техніки угруповання військ. Озброєння та військова техніка. 2017. №3(15), C. 66-70. 
8. Дюбанов, О.О. Системний підхід до врегулювання проблемних процесів автотехнічного забезпечення Сухопутних військ Збройних Сил України. Збірник наукових праць Центру воєнностратегічних досліджень Національного університету оборони України імені Івана Черняховського. 2017. № 3. С. 119-125. URL: http://nbuv.gov.ua/UJRN/Znpcvsd_ 2017_3_23

9. Шишанов, М.О. Веретнов, А.О. Кондратюк, І.В. Горбачевський, С.А. Концептуальні основи розробки програм забезпечення ремонтопридатності складних технічних систем. Сучасні інформаційні технології у сорері безпеки та оборони, НУОУ. 2020. №3(39)2020, С. 91-98. URL: http://sit.nuou.org.ua/article/view/214992.

10. Шишанов, М. О. Кондратюк, І. В. Веретнов, А. О. Методичні основи комплексного обґрунтування вимог до відновлювальності складних технічних систем. Сучасні інформаційні технології у сфрері безпеки та оборони, НУОУ. 2021. №1(40)2021, С. 85-94. URL: http://sit.nuou.org.ua/.

11. Животовський, Р. М. Петрук, С. М. Нікіфоро, М. М. Особливості вдосконалення і розвитку системи діагностичного забезпечення на основі методу інтелектуальної підтримки. Озброєння та військова техніка. 2016. №4(12). С. 57-60.

12. Овчаренко, Ю. $€$ Формулювання математичної моделі багатокритеріального вибору військової техніки та результатів оцінки точності розв'язання задачі багатовекторної оптимізації. Автомобільний транспорт. 2011, Вип. 29. C. 71-75.

13. Боев, А. С. Бывших, Д. М. Ярыгин, Ю. Н. Компенсация факторов неопределенности при обосновании задач радиоэлектронной борьбы в операциях (боевых действия): методический аспект. Проблемы анализа риска. Том 13. - 2016. № 5. C. 36-42.
14. Чепков, І. Б. Ланецький, Б. М. Леонтьєв, О. Б. Лук'янчук, В. В. Методичний підхід до обґрунтування раціонального співвідношення обсягів розробки, закупівлі та ремонту озброєння й військової техніки. Озброєння $\mathrm{ma}$ військова техніка. Київ, 2014. №3. С. 9-14.

15. Середенко, М. М. Єфімов, Г. В. Проблеми збалансованості та перспективи розвитку системи озброєння Сухопутних Військ Збройних Сил України. Військовотехнічний збірник. 2014. №2(11). С. 46-51.

16. Дачковського В.О., Левченко М.А. (2021) Напрямки розвитку рухомих засобів ремонту озброєння та військової техніки. Scientific Collection "InterConf», (65): with the Proceedings of the 4 the International Scientific and Practical Conference "Global and Regional Aspects of Sustainable Development» (July 6-8, 2021). Copenhagen, Denmark: Berlitz Forlag,. p. 174-176.

17. Kondratyuk, I. (2021). Analysis of the development of mobile maintenance and repair of military vehicles. Journal of Scientific Papers "Social Development and Security», 11(1), 52-69. DOI: 10.33445/sds.2021.11.1.6

18. Dachkovsky , V., \& Kondratiuk , I. (2020). Analysis of the fleet of military vehicles that will need to be restored by rolling stock maintenance and repair. Journal of Scientific Papers "Social Development and Security", 10(6), 216-228. DOI: 10.33445/sds.2020.10.6.20

19. Дачковський, В., \& Обозненко, Є. (2021). Методика визначення виробничих можливостей $з$ ремонту озброєння та військової техніки. Збірник наукових праць ヘ'OГОг. URL: DOI: 10.36074/logos11.06.2021.v1.21

20. Сальнікова, О.Ф. (2011). Формалізація задачі розподілу технопарків між регіонами й підходи до ії вирішення. Збірник наукових праць Військового інституту Київського національного університету імені Тараса Шевченка. №30. C. 182-187. 
21. Шишанов, М. О. Гуляєв, А.В. Шевцов, М.М. обґрунтування методу моделювання процесу функціонування системи відновлення озброєння та військової техніки угруповання військ. Озброєння та військова техніка. 2017. №1(13). С. 75-77.

22. Дачковського В.О., Левченко М.А. (2021) Оцінювання ефективності застосування рухомих засобів ремонту озброєння та військової техніки Scientific Collection "InterConf", (66): with the Proceedings of the 9th International Scientific and Practical Conference "Challenges in Science of Nowadays" (July 16-18, 2021). Washington, USA: EnDeavours Publisher,. p. 510-513.

23. Тарасенко П.Н., Цыганков В.Н. (2009) Перспективные подвижные средства восстановления вооружения и военной техники. Новости науки и технологий. №2 (11). С. 26-32.

24. Шишанов М.О., Гуляєв А.В., зубарєв О.В., Шевцов М.М. (2017) Методологія обґрунтування тактико-технічних вимог до технічних засобів відновлення. Озброєння та військова техніка. ЦНДІ ОВТ, М. Київ, 2(14), C. 80-83.

25. Старцев В.В., Рогозін І.В., Литовченко Д.М. (2016) Перспективи створення сучасної рухомої автомобільної ремонтної майстерні вітчизняного виробництва. Системи озброєння і військова техніка. ХНУПС ім. І. Кожедуба, м. Харків, № 2(46). C. $150-154$.

26. Пат. 122446 Україна, МПК (2009) ) F41 H 7/00. Базова гусенична платформа модульного типу / Дачковський В.О., Овчаренко І.В., Ярошенко О.В., Сампір О.М., Куровська Т.Ю. - заявник і володар патенту Дачковський В.О. - № a201812481; заяв. 17.12.2018; опубл. 10.11.2020; Бюл. № 21/2020.

27. Пат. 134972 Україна, МПК (2009) ) F41 H 7/00. Базова колісна платформа модульного типу / Дачковський В.О. заявник і володар патенту Дачковський В.О. - № u2019 00225; заяв. 09.01.2019; опубл. 10.06.2019; Бюл. № 11/2019.
28. Дачковського В.О., Левченко М.А. (2021). Методичний підхід до визначення можливостей ремонтно-відновлюваних органів з евакуації пошкоджених зразків озброєння та військової техніки. Title of article or abstract. Scientific Collection "InterConf", (64): with the Proceedings of the 3rd International Scientific and Practical Conference "Science, Education, Innovation: Topical Issues and Modern Aspects" (June 2526, 2021) Tallinn, Estonia; p. 287-290.

29. Павловський О. В., Сисоєв О. О. Значення досвіду технічного забезпечення військ у Великій Вітчизняній війні для розвитку сучасної системи технічного забезпечення. Наука і техніка ПС ЗС України: наук.-техн. журн./ ХУПС. Х., 2010. № 1 (3). С. 202-205.

30. Сисоєв О.О. Проблеми, тенденції і перспективи розвитку системи технічного забезпечення військ (сил) у війнах i збройних конфліктах кінця XX і початку XXI століття. К.: НАОУ, 2004. - 105 с.

31. Дачковський В.О., Левченко М.А. (2021) Математична модель виконання завдань 3 технічної розвідки. Міжнародний науковий журнал «Грааль науки» № 6 (Червень, 2021): за матеріалами । Міжнародної науково-практичної конференції «Modern science: concepts, theories and methods of basic and applied research», що проводилася 25 червня 2021 року «International Centre Corporative Management» (Відень, Австрія). р. 87-90.

32. Дачковського В.О., Левченко М.А. Аналіз розвитку засобів евакуації пошкоджених зразків озброєння та військової техніки. Scientific Collection "InterConf", (68): with the Proceedings of the 3-rd International Scientific and Practical Conference "Experimental and Theoretical Research in Modern Science" (July 26-28, 2021). Kishinev, Moldova: Giperion Editura, 2021. p.

33. Дачковський , В., \& Цуркан , М. (2021). Методика оцінювання можливості виконання заходів з ремонту озброєння та військової техніки. Збірник наукових праць 


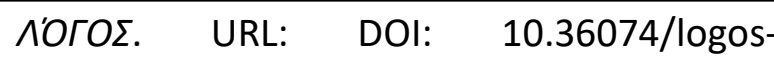

19.03.2021.v1.49

34. Dachkovskyi, V., Sampir, O., \& Horbachova, Y. (2020). Methodical approach to evaluation of economic efficiency of repairing the weapons and military equipment. VUZF Review, 5(1), 22-30. DOI: 10.38188/25349228.20.1.03

35. Dachkovskyi, V. (2019). Methodology of justification of tactical and technical requirements for movable means of repairing arms and military equipment. Journal of Scientific Papers "Social Development and Security", 9(6), 86-101. DOI: 10.33445/sds.2019.9.6.7

36. Ковтуненко, А. П. Шишанов, М. А. Зубарев, А. В. Оністрат А. А. Основы военнотехнических исследований. Теория и приложения (монография в 3 т. Т.3. Синтех систем технического обеспечения эксплуатации и ремонта вооружения и военной техники. К., 2012, 424 с.

37. Кондратюк, І.В., Сампір, І.А., Веретнов, А.О. Методичні основи обґрунтування перспектив розвитку рухомих засобів відновлення військової автомобільної техніки Збройних Сил України. Збірник наукових праць “А'ОГОг" з матеріалами Міжнародна науково-практична конференція "Наукова практика: сучасні та класичні методи дослідження" 26 лютого
2021 року, Бостон, США С. 140-142. URL: https://ojs.ukrlogos.in.ua/index.php/logos/i ssue/view/26.02.2021/458.

38. Dachkovskyi, V. (2020). Methodology of explanation of tactical and technical requirements for means of evacuation of weapons and military equipment. Journal of Scientific Papers "Social Development and Security", 10(3), 104-113. DOI: 10.33445/sds.2020.10.3.9

39. Ощепков П.П., Храпова М.Ю. Модель расчёта трудоёмкости работ по техническому обслуживанию и ремонту автомобилей. Интернет-журнал “Науковедение". 2016. Том 8, №3, С. 1-9.

40. Дачковський, В. О., Ярошенко, О. В., Кузнецов, І. Б., Овчаренко І. В. Основи організації відновлення озброєння та військової техніки. К.: НУОУ ім. Івана Черняховського, 2019, 136 с.

41. Овсиевич, Б. Л. Модели формирования организационных структур. Ленинград: Наука, 1979, 160 C.

42. Kotsyuruba, V. (2017). Formulation of the problem and substantiation of the set of principles of constructing an adaptive mineclearance system under conditions of resource constraints. Journal of Scientific Papers "Social Development and Security", 2(2), 3-11. DOI: 10.5281/zenodo.1117323

\title{
Формализация задачи выбора перспективных подвижных средств технического обслуживания и ремонта военной автомобильной техники
}

\author{
Игорь Кондратюк * 1 А \\ * Corresponding author: ${ }^{1}$ адъюнкт кафедры, e-mail: igorek2410@ukr.net, ORCID: 0000-0001-9408-1435 \\ А Национальный университет обороны Украины имени Ивана Черняховского, г. Киев, Украина
}

\begin{abstract}
Аннотация
Интенсивное развитие военной автомобильной техники предъявляет повышенные требования к подвижным средствам технического обслуживания и ремонта военной автомобильной техники во время их применения по назначению. Необходимо понимать, что закупка одной номенклатуры военной автомобильной техники влечет за собой потребность в создании в Вооруженных Сил Украины ремонтных комплектов для ремонтновосстановительных подразделений (воинских частей) разного уровня иерархии, которые
\end{abstract}


будут применяться для обслуживания и ремонта данных образцов военной автомобильной техники. Кроме того, необходимо учитывать, что существующие на вооружении подвижные средства технического обслуживания и ремонта военной автомобильной техники не в полной мере приспособлены к работе на новых образцах из-за отсутствия технологического оборудования. Итак, в настоящее время возникают противоречия между возможностями ремонтных подразделений на вооружении которых находятся морально и физически устаревшие подвижные средства технического обслуживания и ремонта, и потребностями в техническом обслуживании и ремонте новых образцов военной автомобильной техники, принятых на вооружение в последние годы, в которых завершился гарантийный срок эксплуатации. Устаревшее оборудование существующих подвижных средств технического обслуживания и ремонта, отсутствие средств диагностики, современных средств связи, инструмента и специальных приборов, которые предназначены для ремонта принятых на вооружение новых образцов военной автомобильной техники, снижают производственные возможности ремонтных подразделений (воинских частей), а иногда вообще невозможным вернуть в строй военную автомобильную технику, какая требует технического обслуживания или ремонта.

Поэтому, в статье на основе сравнительного анализа возможностей подвижных средств технического обслуживания и ремонта и потребности в техническом обслуживании и ремонте новых образцов военной автомобильной техники, характера боевых и эксплуатационных повреждений военной автомобильной техники в локальных войнах и вооруженных конфликтах, операции Объединенных сил на территории Украина, проведено сравнение качественных и количественных характеристик. Сформулированы научная задача о принципах построения рациональной структуры подвижных средств технического обслуживания и ремонта военной автомобильной техники и их элементов на разных уровнях иерархии.

Ключевые слова: обслуживание, ремонт, техника, автомобиль.

\title{
Formalization of the task of choosing promising rolling stock for maintenance and repair of military vehicles
}

\author{
Igor Kondratiuk * 1 A \\ * Corresponding author: ${ }^{1}$ PhD student, e-mail: igorek2410@ukr.net, ORCID: 0000-0001-9408-1435 \\ A National Defense University of Ukraine named after Ivan Cherniakhovskyi, Kyiv, Ukraine
}

\begin{abstract}
Intensive development of military automobile technology is raised by increased requirements for moving means of maintenance and repair of military automotive equipment during their appointment. It should be understood that the purchase of one nomenclature of military automobile technology entails the need to create repair kits in the Armed Forces for repair and restoration units (military units) of different levels of the hierarchy that will be used to maintain and repair these samples of military automobile technology. In addition, it should be borne in mind that existing military motor vehicles and repair of military automotive techniques are not fully adapted to perform work on new samples due to the lack of technological equipment. Consequently, there are no contradictions between the possibilities of repair units on arms, which are morally and physically obsolete movable means of maintenance and repair, and the needs of maintenance and repair of new samples of military automotive techniques adopted in recent years in recent years in which completed guarantee lifetime. Outdated equipment of existing moving means of maintenance and repair, lack of diagnostic tools, modern means of communication, tools and special devices that are intended for repair of new samples of military automotive techniques, reduce the production capabilities of repair units (military units), and
\end{abstract}


sometimes Generally make it impossible to return to the operation of military automotive engineering, which requires maintenance or repair.

Therefore, in article based on comparative analysis of the possibilities of moving means of maintenance and repair and needs for maintenance and repair of new samples of military automotive technology, the nature of combat and operational damage to military automotive technology in local wars and armed conflicts, operations of the united forces in the territory Ukraine conducted a comparison of quality and quantitative characteristics. The scientific task was formulated regarding the principles of constructing a rational structure of moving means of maintenance and repair of military automotive machinery and their elements at different levels of the hierarchy.

Keywords: maintenance, repair, equipment, car.

\section{References}

1. Havrylyuk I.YU., Mats'ko O.Y., Dachkovs'kyy V.O. (2019). Kontseptual'ni osnovy upravlinnya potokamy $v$ systemi lohistychnoho zabezpechennya Zbroynykh Syl Ukrayiny. "Suchasni informatsiyni tekhnolohiyi u sferi bezpeky ta oborony", NUOU. № 1(34) S. $37-44$.

2. Vlasov, I. O. Vorobyov, O. M. Nakonechnyy, O. V. Sereda, YU. S. (2020). Obgruntuvannya kontseptual'nykh ta naukovykh pidkhodiv shchodo rozvytku yedynoyi systemy lohistyky v Zbroynykh Sylakh Ukrayiny. Zbirnyk naukovykh prats' Kharkivs'koho natsional'noho universytetu Povitryanykh Syl imeni Ivana Kozheduba - Kharkiv. № 2(64). S. 12-18.

3. Kyvliuk, V., \& Gannenko, Y. (2018). Improvement of the system of material resources of the armed forces of Ukraine. Journal of Scientific Papers "Social Development and Security», 4(2), 49-58. DOI: 10.5281/zenodo.1231404

4. Dachkovskyi, V. (2019). Methodology of justification of tactical and technical requirements for movable means of repairing arms and military equipment. Journal of Scientific Papers "Social Development and Security», 9(6), 86-101. DOI: 10.33445/sds.2019.9.6.7

5. Rozporyadzhennya Kabinetu Ministriv Ukrayiny vid 14 chervnya 2017 r. № 398-r, m. Kyiv. Available from: https://zakon.rada.gov.ua/laws/show/3982017-r\#Text.
6. Rozporyadzhennya Kabinetu Ministriv Ukrayiny vid 21 lypnya 2021 r. № 825-r m. Kyiv. Available from: https://zakon.rada.gov.ua/laws/show/8252021-\%D1\%80\#Text.

7. Shyshanov, M. O. Shevtsov, M.M. Chechenkova, O.L. (2017). Metodolohichni osnovy strukturnoho syntezu system vidnovlennya ozbroyennya ta viys'kovoyi tekhniky uhrupovannya viys'k. Ozbroyennya ta viys'kova tekhnika. № 3(15), S. 66-70.

8. Dyubanov, O.O. (2017). Systemnyy pidkhid do vrehulyuvannya problemnykh protsesiv avtotekhnichnoho zabezpechennya Sukhoputnykh viys'k Zbroynykh Syl Ukrayiny. Zbirnyk naukovykh prats' Tsentru voyennostratehichnykh doslidzhen' Natsional'noho universytetu oborony Ukrayiny imeni Ivana Chernyakhovs'koho. № 3. S. 119-125. Available from: http://nbuv. gov.ua/UJRN/Znpcvsd_2017_3_23.

9. Shyshanov, M. O. Veretnov, A. O. Kondratyuk, I. V. Horbachevs'kyy, S. A. (2020). Kontseptual'ni osnovy rozrobky prohram zabezpechennya remontoprydatnosti skladnykh tekhnichnykh system. "Suchasni informatsiyni tekhnolohiyi u sferi bezpeky ta oborony", NUOU. № 3(39)2020, S. 91 - 98. Available

from: http://sit.nuou.org.ua/article/view/214992.

10. Shyshanov, M.O. Kondratyuk, I.V. Veretnov, A.O. (2021). Metodychni osnovy kompleksnoho obgruntuvannya vymoh do vidnovlyuval'nosti skladnykh tekhnichnykh system. "Suchasni informatsiyni tekhnolohiyi 
u sferi bezpeky ta oborony", NUOU. №1(40)2021, S. 85 - 94. Available from: http://sit.nuou.org.ua/.

11. Zhyvotovs'kyy, R.M. Petruk, S.M. Nikiforo, M.M. (2016). Osoblyvosti vdoskonalennya i rozvytku systemy diahnostychnoho zabezpechennya na osnovi metodu intelektual'noyi pidtrymky. Ozbroyennya ta viys'kova tekhnika. №4(12). S. 57-60.

12. Ovcharenko, YU. YE. (2021). Formulyuvannya matematychnoyi modeli bahatokryterial'noho vyboru viys'kovoyi tekhniky ta rezul'tativ otsinky tochnosti rozv"yazannya zadachi bahatovektornoyi optymizatsiyi. Avtomobil'nyy transport. Vyp. 29. S. 71-75.

13. Boev, A.S. Byvshykh, D.M. Yaryhyn, YU.N. (2016). Kompensatsyya faktorov neopredelennosty pry obosnovanyy zadach radyoélektronnoy bor'by $v$ operatsyyakh (boevykh deystvyyakh): metodycheskyy aspekt. Problemy analyza ryska. Tom 13. №5. S. 36-42.

14. Chepkov, I.B. Lanets'kyy, B.M. Leont'yev, O.B. Luk"yanchuk, V.V. (2014). Metodychnyy pidkhid do obgruntuvannya ratsional'noho spivvidnoshennya obsyahiv rozrobky, zakupivli ta remontu ozbroyennya y viys'kovoyi tekhniky. Ozbroyennya ta viys'kova tekhnika. - Kyiv, №3. S. 9-14.

15. Seredenko, M.M. Yefimov, H.V. (2014). Problemy zbalansovanosti ta perspektyvy rozvytku systemy ozbroyennya Sukhoputnykh Viys'k Zbroynykh Syl Ukrayiny. Viys'kovo-tekhnichnyy zbirnyk. №2(11). S. 4651.

16. Dachkovs'koho V.O., Levchenko M.A. (2021) Napryamky rozvytku rukhomykh zasobiv remontu ozbroyennya ta viys'kovoyi tekhniky. Scientific Collection «InterConf», (65): with the Proceedings of the 4 the International Scientific and Practical Conference "Global and Regional Aspects of Sustainable Development» (July 6-8, 2021). Copenhagen, Denmark: Berlitz Forlag,. p. 174-176.
17. Kondratyuk, I. (2021). Analysis of the development of mobile maintenance and repair of military vehicles. Journal of Scientific Papers "Social Development and Security», 11(1), 52-69. DOI: 10.33445/sds.2021.11.1.6

18. Dachkovsky , V., \& Kondratiuk , I. (2020). Analysis of the fleet of military vehicles that will need to be restored by rolling stock maintenance and repair. Journal of Scientific Papers "Social Development and Security", 10(6), 216-228. DOI: 10.33445/sds.2020.10.6.20

19. Dachkovs'kyy, V., \& Oboznenko, YE. (2021). Metodyka vyznachennya vyrobnychykh mozhlyvostey $z$ remontu ozbroyennya ta viys'kovoyi tekhniky. Zbirnyk naukovykh prats' LÓHOS. DOI: 10.36074/logos11.06.2021.v1.21.

20. Sal'nikova, O. F. Formalizatsiya zadachi rozpodilu tekhnoparkiv mizh rehionamy y pidkhody do yiyi vyrishennya. Zbirnyk naukovykh prats' Viys'kovoho instytutu Kyyivs'koho natsional'noho universytetu imeni Tarasa Shevchenka. 2011. № 30. S. 182-187.

21. Shyshanov, M. O. Hulyayev, A.V. Shevtsov, M.M. (2017). Obgruntuvannya metodu modelyuvannya protsesu funktsionuvannya systemy vidnovlennya ozbroyennya ta viys'kovoyi tekhniky uhrupovannya viys'k. Ozbroyennya ta viys'kova tekhnika. №1(13). S. 75-77.

22. Dachkovs'koho V.O., Levchenko M.A. (2021) Otsinyuvannya efektyvnosti zastosuvannya rukhomykh zasobiv remontu ozbroyennya ta viys'kovoyi tekhniky Scientific Collection "InterConf", (66): with the Proceedings of the 9th International Scientific and Practical Conference "Challenges in Science of Nowadays" (July 16-18, 2021). Washington, USA: EnDeavours Publisher,. r. 510-513.

23. Tarasenko P.N., TSyhankov V.N. (2009) Perspektyvnye podvyzhnye sredstva vosstanovlenyya vooruzhenyya y voennoy tekhnyky. Novosty nauky y tekhnolohyy. № 2 (11) S. 26-32. 
24. Shyshanov M.O., Hulyayev A.V., Zubaryev O.V., Shevtsov M.M. (2017) Metodolohiya obgruntuvannya taktyko-tekhnichnykh vymoh do tekhnichnykh zasobiv vidnovlennya. Ozbroyennya ta viys'kova tekhnika. TSNDI OVT, m. Kyiv, 2(14), S. 80-83.

25. Startsev V. V., Rohozin I. V., Lytovchenko D. M. (2016) Perspektyvy stvorennya suchasnoyi rukhomoyi avtomobil'noyi remontnoyi maysterni vitchyznyanoho vyrobnytstva. Systemy ozbroyennya i viys'kova tekhnika. KHNUPS im. I. Kozheduba, m. Kharkiv, № 2(46). S. 150-154.

26. Pat. 122446 Ukrayina, MPK (2009) ) F41 H 7/00. Bazova husenychna platforma modul'noho typu / Dachkovs'kyy V.O., Ovcharenko I.V., Yaroshenko O.V., Sampir O.M., Kurovs'ka T.YU. - zayavnyk i volodar patentu Dachkovs'kyy V.O. - № a201812481; zayav. 17.12.2018; opubl. 10.11.2020; Byul. № 21/2020.

27. Pat. 134972 Ukrayina, MPK (2009) ) F41 H 7/00. Bazova kolisna platforma modul'noho typu / Dachkovs'kyy V.O. - zayavnyk i volodar patentu Dachkovs'kyy V.O. - № u2019 00225; zayav. 09.01.2019; opubl. 10.06.2019; Byul. № 11/2019.

28. Dachkovs'koho V.O., Levchenko M.A. (2021). Metodychnyy pidkhid do vyznachennya mozhlyvostey remontno-vidnovlyuvanykh orhaniv z evakuatsiyi poshkodzhenykh zrazkiv ozbroyennya ta viys'kovoyi tekhniky. Title of article or abstract. Scientific Collection "InterConf", (64): with the Proceedings of the 3rd International Scientific and Practical Conference "Science, Education, Innovation: Topical Issues and Modern Aspects" (June 25-26, 2021) Tallinn, Estonia; p. 287-290.

29. Pavlovs'kyy O.V., Sysoyev O. O. (2010). Znachennya dosvidu tekhnichnoho zabezpechennya viys'k u Velykiy Vitchyznyaniy viyni dlya rozvytku suchasnoyi systemy tekhnichnoho zabezpechennya. Nauka i tekhnika PS ZS Ukrayiny: nauk.-tekhn. zhurn./ KHUPS. KH., № 1 (3). S. 202-205.
30. Sysoyev O.O. Problemy, tendentsiyi i perspektyvy rozvytku systemy tekhnichnoho zabezpechennya viys'k (syl) u viynakh i zbroynykh konfliktakh kintsya KHKH i pochatku KHKHI stolittya. Kyiv: NAOU, 2004. $-105 \mathrm{~s}$.

31. Dachkovs'kyy V.O., Levchenko M.A. (2021) Matematychna model' vykonannya zavdan' z tekhnichnoyi rozvidky. Mizhnarodnyy naukovyy zhurnal "Hraal' nauky» № 6 (Cherven', 2021): za materialamy । Mizhnarodnoyi naukovo-praktychnoyi konferentsiyi «Modern science: concepts, theories and methods of basic and applied research", shcho provodylasya 25 chervnya 2021 roku «International Centre Corporative Management» (Viden', Avstriya). r. 87-90.

32. Dachkovs'koho V.O., Levchenko M.A. Analiz rozvytku zasobiv evakuatsiyi poshkodzhenykh zrazkiv ozbroyennya ta viys'kovoyi tekhniky. Scientific Collection "InterConf", (68): with the Proceedings of the 3-rd International Scientific and Practical Conference "Experimental and Theoretical Research in Modern Science" (July 26-28, 2021). Kishinev, Moldova: Giperion Editura, 2021. $r$.

33. Dachkovs'kyy , V., \& Tsurkan , M. (2021). Metodyka otsinyuvannya mozhlyvosti vykonannya zakhodiv z remontu ozbroyennya ta viys'kovoyi tekhniky. Zbirnyk naukovykh prats' LÓHOS. URL: DOI: 10.36074/logos-19.03.2021.v1.49.

34. Dachkovskyi, V., Sampir, O., \& Horbachova, Y. (2020). Methodical approach to evaluation of economic efficiency of repairing the weapons and military equipment. VUZF Review, 5(1), 22-30. DOI: 10.38188/25349228.20.1.03

35. Dachkovskyi, V. (2019). Methodology of justification of tactical and technical requirements for movable means of repairing arms and military equipment. Journal of Scientific Papers "Social Development and Security», 9(6), 86-101. DOI: 10.33445/sds.2019.9.6.7 
36. Kovtunenko, A.P. Shyshanov, M.A. Zubarev, A.V. Onistrat A.A. Osnovy voennotekhnycheskykh yssledovanyy. Teoryya y prylozhenyya (monohrafyya $v \quad 3$ t. T.3. Syntekh system tekhnycheskoho obespechenyya ékspluatatsyy y remonta vooruzhenyya y voennoy tekhnyky. Kyiv, 2012, 424 s.

37. Kondratyuk, I.V. Sampir, I.A. Veretnov, A.O. Metodychni osnovy obgruntuvannya perspektyv rozvytku rukhomykh zasobiv vidnovlennya viys'kovoyi avtomobil'noyi tekhniky Zbroynykh Syl Ukrayiny. Zbirnyk naukovykh prats' "LÓHOS" z materialamy Mizhnarodna naukovo-praktychna konferentsiya "Naukova praktyka: suchasni ta klasychni metody doslidzhennya" 26 Iyutoho 2021 roku, Boston, SSHA S. 140-142. URL: https: // ojs.ukrlogos. in. ua/index. php/logos/issue/view/26.02.2021/458.

38. Dachkovskyi, V. (2020). Methodology of explanation of tactical and technical requirements for means of evacuation of weapons and military equipment. Journal of
Scientific Papers "Social Development and Security», 10(3), 104-113. DOI: 10.33445/sds.2020.10.3.9

39. Oshchepkov P.P., Khrapova M.YU. (2016). Model' raschëta trudoëmkosty rabot po tekhnycheskomu obsluzhyvanyyu y remontu avtomobyley. Ynternet-zhurnal "Naukovedenye". Tom 8, №3, S. 1-9.

40. Dachkovs'kyy, V.O., Yaroshenko, O.V., Kuznetsov, I.B., Ovcharenko I.V.Osnovy orhanizatsiyi vidnovlennya ozbroyennya ta viys'kovoyi tekhniky. Kyiv: NUOU im. Ivana Chernyakhovs'koho, 2019, 136 S.

41. Ovsyevych B.L. Modely formyrovanyya orhanyzatsyonnykh struktur. Lenynhrad: Nauka, 1979, $160 \mathrm{~S}$.

42. Kotsyuruba, V. (2017). Formulation of the problem and substantiation of the set of principles of constructing an adaptive mineclearance system under conditions of resource constraints. Journal of Scientific Papers "Social Development and Security", 2(2), 3-11. DOI: 10.5281/zenodo.1117323 